Egyptian Journal of Aquatic Biology \& Fisheries

Zoology Department, Faculty of Science,

Ain Shams University, Cairo, Egypt.

ISSN $1110-6131$

Vol. 24(2): 342 - 352 (2020)

www.ejabf.journals.ekb.eg

\title{
Age precision and growth rate of Rhabdosargus haffara (Forsskål, 1775) from Hurghada
} fishing area, Red Sea, Egypt

\author{
Yassein A. A. Osman ${ }^{1 *}$; Sahar F. Mehanna ${ }^{1}$; Samia M. El-Mahdy ${ }^{1}$; \\ Ashraf S. Mohammad ${ }^{1}$; Kelig Mahe ${ }^{2}$
}

1. National Institute of Oceanography and Fisheries, Egypt

2. Ifremer, Fisheries Laboratory, Sclerochronology Centre, Boulogne-sur-Mer, France

*Corresponding Author: yasseinahmed66@yahoo.com

ARTICLE INFO

Article History:

Received: March 18, 2020

Accepted: April 8, 2020

Online: April 11, 2020

Keywords:

Age precision, growth,

Rhabdosargus haffara,

Hurghada,

Red Sea,

Egypt

stock assessment.

\section{ABSTRACT}

The age and growth of the haffara seabream, Rhabdosargus haffara (Forsskål, 1775) from Hurghada fishing area, Red sea, Egypt, were investigated using a sample of 466 specimens. The fish length varied between 12.7 and $27.2 \mathrm{~cm}$ and the weight from 38.1 to $293.2 \mathrm{~g}$. Samples were collected from the artisanal fisheries during the fishing season from August 2018 to July 2019. The relationship between the body lengths (total, fork and standard length in $\mathrm{cm}$ ) and the body weight $(\mathrm{g}$ ) was found to be significant $(p<0.05)$. The relationship between the body length and weight regarding the sex effect was insignificant for all samples $(\log \mathrm{W}-\log \mathrm{TL}$, ANCOVA, $p>0.05$ ). The relationship between length and weight was estimated by a power regression function, with a scaling factor at $\mathrm{a}=0.0106$ for both females and males and 0.0107 for the combined sexes, the exponent $b=3.13,3.13$ and 3.129 for females, males and for all samples, respectively. Age was determined using the whole otolith and the maximum age of haffara was 5 years old for females and males. The otolith readings indicated good agreement between the two readers with an agreement $=88.35 \%, \mathrm{CV}=3.93 \%$ and $\mathrm{APE}=2.78 \%$. The von Bertalanffy growth parameters were estimated at $\mathrm{TL}_{\infty}=30.13 \mathrm{~cm}, \mathrm{k}=0.35 \mathrm{y}^{-1}$, and $\mathrm{t}_{0}=-0.24 \mathrm{y}$ for females, $\mathrm{TL}_{\infty}=$ $30.49 \mathrm{~cm}, \mathrm{k}=0.36 \mathrm{y}^{-1}$, and $\mathrm{t}_{0}=-0.26 \mathrm{y}$ for males, $\mathrm{TL}_{\infty}=30,47 \mathrm{~cm}, \mathrm{k}=0.36 \mathrm{y}^{-1}$, and $\mathrm{t}_{0}=-0.26 \mathrm{y}$ for the combined sexes.

\section{INTRODUCTION}

Family Sparidae (commonly known as porgies and seabream) is a relatively large family with 38 genera and 159 species (fishbase, 2019). It is distributed in tropical and temperate Atlantic, Indian and Pacific Oceans usually most common along the shore from shallow water (including estuaries), to deeper water as demersal inhabitants of the continental shelf and slope (Bauchot and Smith, 1984). Family Sparidae is commercially very important worldwide and constitute an important part of the small-scales fisheries such as gillnet, trammel net and hand line (Mehanna, 2001, 2007; Al Mamry et al., 2009; Mehanna et al., 2012; El-Drawany, 2015; 
Siddiqui and Masroor, 2014). Rhabdosargus haffara (Forsskål 1775) belongs to family Sparidae and is commonly known as haffara sea bream or haffara as the fishermen called. It is widely presented in the Egyptian Red Sea with prices ranged between 60-80 Egyptian pounds. It inhabits different areas such as shallow water, coral reefs, and lives near the sandy or mudsandy bottoms. It feeds mainly on mollusks and crustaceans, which are crushed with its developed molars. There are many studies dealing with the biology, dynamics and fishery status of Sparid species in the Egyptian waters, but very few authors were studied the biology and dynamics of $R$. haffara (Mehanna, 2001; El-Drawany, 2015; Mehanna et al., 2016).

As there are insufficient information about the biology, species discrimination and fisheries status especially in Hurghada fishing area, Red sea, Egypt, the current work was suggested to fill such gab. It will provide information on the age, growth and length-weight relationship of haffara seabream in the Red Sea for the future stock assessment studies.

\section{MATERIALS AND METHODS}

\section{Study area and sampling}

The study area is located in front of Hurghada city in the northern part of the Red Sea between latitudes $27^{\circ} 10^{\prime} \mathrm{N}-27^{\circ} 30^{\prime} \mathrm{N}$ and longitudes $33^{\circ} 70^{\prime} \mathrm{E}-33^{\circ} 85^{\prime}$ E. Random samples of haffara seabream were collected from the landing site in Hurghada during the fishing season 2018- 2019. Haffara seabream were caught as a component of small scale fisheries including gillnet, trammel net and hook and line.

\section{Laboratory work}

All fish collected were measured for the total, standard and fork lengths (TL, SL and FL) to the nearest $\mathrm{mm}$, and weighed to the nearest $0.1 \mathrm{~g}$. The sagittal otolith was removed, cleaned with Sodium hypochlorite, then dried and stored in paper envelopes for age determination.

\section{Methods}

The relationship between length-weight was calculated as $\mathrm{W}=\mathrm{a} \mathrm{L}^{\mathrm{b}}$ (Le Cren, 1951) where $\mathrm{W}$ is the total weight (g), $\mathrm{L}$ is the total length; $\mathrm{a}$ is the intercept and $\mathrm{b}$ is the slope of the equation. Covariance analyses (ANCOVA) was used to evaluate variances between the fitted length-weight relationships for both sexes. To estimate the parameters of the length- weight correlation, the least-square linear regression was fitted to the base-10 logarithm of the data as follows: $\log \mathrm{W}=\log \mathrm{a}+\mathrm{b} \log \mathrm{L}$

The growth rings on the otoliths were counted to determine the maximum life span of the Haffara sea bream from Hurghada. The sagittal otolith was removed from each specimen, cleaned and kept until the investigation time. In order to increase the transparency of the otoliths for viewing the growth rings, the otoliths were rinsed in sodium hypochlorite acid for few seconds before examination. Then, the otoliths were immersed in few drops of glycerol and examined with stereomicroscope (Carl Zeiss Discovery v20 connects to AxioCam ERc5s camera with software) with reflected light and a black background and 20x as the magnification. 
The following otolith measurements were taken: $\mathrm{OL}=$ otolith length, $\mathrm{OH}=$ otolith width, $\mathrm{OW}=$ otolith weight and $\mathrm{AS}=$ aspect ratio and then analyzed using the specialized software AxioCam ERc5s.

To validate the age determination, the otolith was investigated by two readers to estimate the reading precision. Coefficient of Variation (CV), Absolute Percent Error (APE) and Percent Agreement (PA; \pm 1 y) were used to estimate the reading precision (Beamish and Fournier, 1981). The Precision metrics were described with the following equation:

$$
\begin{gathered}
\mathrm{CVj}(\%)=100 \times \frac{\sqrt{\sum_{\mathrm{i}=1}^{R} \frac{(X i j+X j)^{2}}{R-1}}}{X_{j}} \\
\operatorname{PAEj}(\%)=100 \times \frac{1}{R} \sum_{i=1}^{R} \frac{|X i j+X j|}{X j} \\
P A=\frac{\sum \mid n \text { diff } \leq 1 \mid}{\mathrm{n}}
\end{gathered}
$$

Where $R$ is the number of times each fish is aged, $X i j$ is the $i($ th) ageing of the $j($ th) fish, $X_{j}$ is the mean age calculated for the $j$ (th) fish, and $n_{\text {diff }}$ is the difference in ageing between the first and second readings.

The von Bertalanffy growth model was applied to describe the growth of haffara sea bream in Hurghada as follows:

$$
\begin{array}{ll}
\text { For length } & \left.\mathrm{TL}_{\mathrm{t}}=\mathrm{TL}_{\infty} *\left(1-\mathrm{e}^{-\mathrm{k}(\mathrm{t}-\mathrm{t})}\right)_{0}\right) \\
\text { For weight } & \mathrm{W}_{\mathrm{t}}=\mathrm{W}_{\infty} *\left(1-\mathrm{e}^{-\mathrm{k}(\mathrm{t}-\mathrm{t})}\right)^{\mathrm{b}}
\end{array}
$$

The constants Lo and K were estimated using the Ford (1993)-Walford (1946) plot, while the constant " $\mathrm{t}_{0}$ " was estimated from the following formula: $\ln [1-(\mathrm{Lt} / \mathrm{L} \infty)]=-\mathrm{k}^{*} \mathrm{t}_{0}+\mathrm{k}^{*} \mathrm{t}$ (von Bertalanffy, 1938). Growth performance index was computed to compare the von Bertalanffy growth of the haffara sea bream fish with other fish species according to the formula $\varnothing^{\prime}=\log _{10} K+2 \log _{10} \operatorname{L} \infty$ (Pauly and Munro 1984).

The potential longevity of age $\left(t_{\max }\right)$ that species can reach was estimated using the growth parameters $\left(\mathrm{k}\right.$ and $\mathrm{t}_{\mathrm{o}}$ ) as $\mathrm{t}_{\max }=3 / \mathrm{k}+\mathrm{t}_{\mathrm{o}}$ (Pauly, 1983). The statistical analyses was performed using an Excel sheet and SPSS 22.

\section{RESULTS}

\section{Length frequency}

Length frequency distribution of $R$. haffara species is graphically represented in Fig. 1. The number of males in the collected samples was 273 specimens and ranged between 14.5$27.2 \mathrm{~cm}$ TL. The females were 179 specimens and their length varied between 15-26.8 cm TL. Fourteen individuals were undetermined with length ranged between 12.7-17 cm. The most frequent lengths in the catch were 16-23 cm TL for males and 18-21 cm TL for females. 


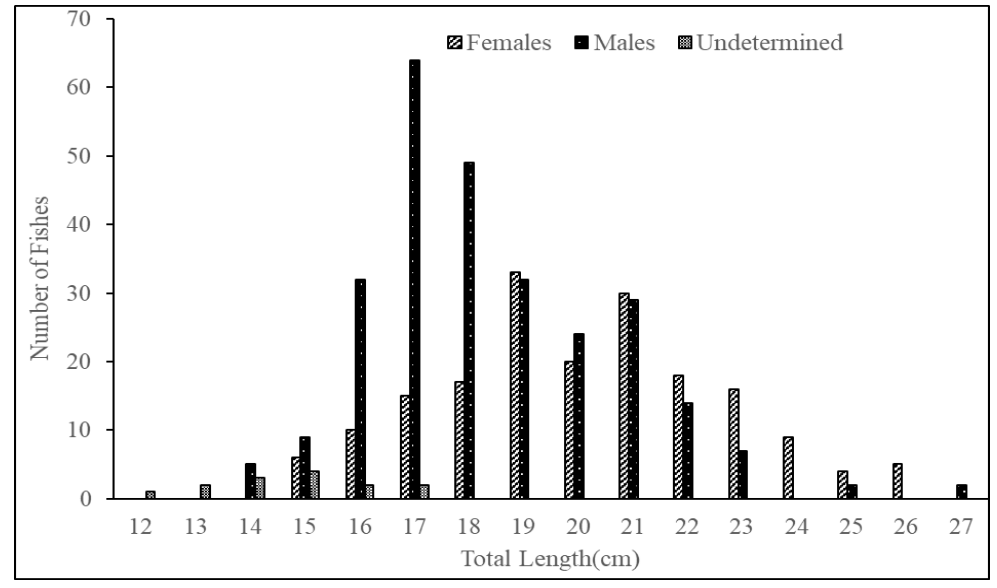

Fig. 1. Length frequency distribution of R. haffara frm Hurghada during 2018-2019

\section{Length- weight and length- length relationships}

A total of 466 samples (273 males, 179 females and 14 unsexed individuals) were collected from the Hurghada fishing area, Red Sea. The mean total lengths were $20.61 \mathrm{~cm} \pm$ 2.31 for the females, $18.81 \mathrm{~cm} \pm 2.08$ for males and $15.24 \mathrm{~cm} \pm 1.57$ for the unsexed individuals. The length-weight relationship (LWR) for the pooled data $\left(\mathrm{W}=0.0107 \mathrm{TL}^{3.129}, \mathrm{n}=\right.$ 466) showed positive allometric growth (ANCOVA, $p>0.05$ ). The equations of the lengthweight relationship for each sex separately are $\mathrm{W}=0.0106 \mathrm{TL}^{3.13}$ and $\mathrm{W}=0.0106 \mathrm{TL}^{3.13}$ for females and males respectively (Fig. 2). The sex effect was non-significant for the lengthweight relationship $(\mathrm{p}>0.05)$.

The length-length relationship was best fitted by linear regression (Table 1) and the resultant equations by fitting the total length to the standard and forked length were:

$$
\begin{array}{ll}
\mathrm{TL}=1.004 \mathrm{SL}+0.087 & \mathrm{r}^{2}=0.949 \\
\mathrm{TL}=1.001 \mathrm{FL}+0.040 & \mathrm{r}^{2}=0.973
\end{array}
$$

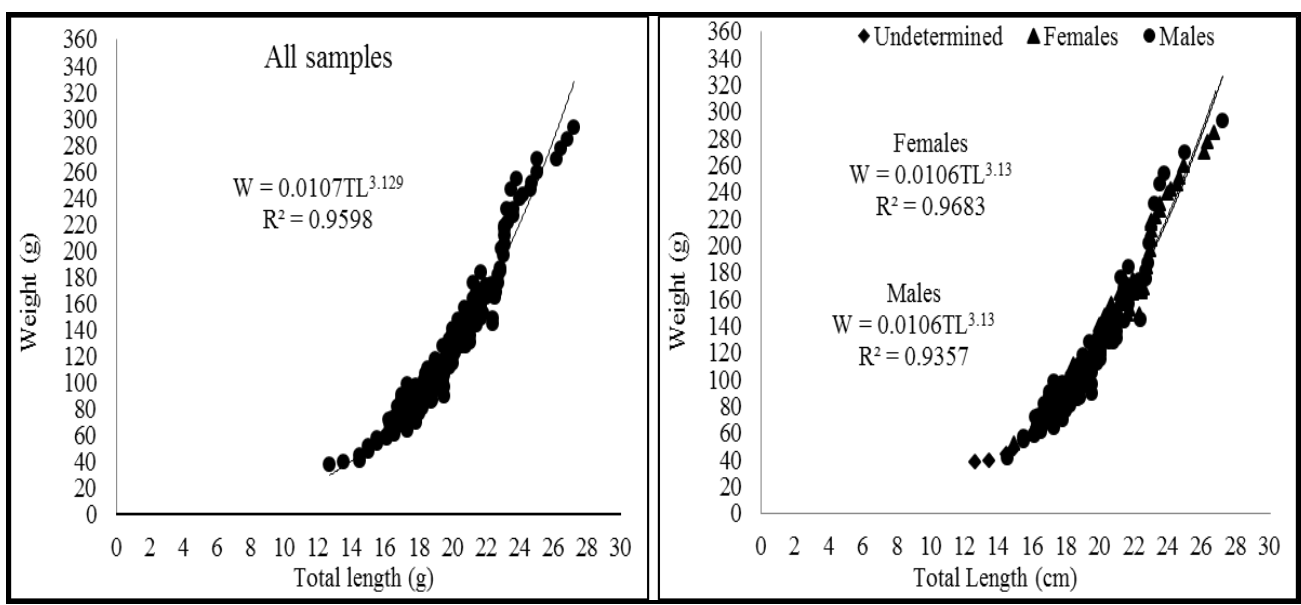

Fig 2. Length- weight relationship for R. haffara from Hurghada 
Table 1. Parameters of length-weight relationship of $R$. haffara (N: sample size; min-max: minimum and maximum total length and weight; $b$ : slope; SD: standard deviation; $\mathrm{r}^{2}$ : coefficient of determination; CI: confidence interval; GT: growth type; A+: positive allometric growth.

\begin{tabular}{|c|c|c|c|c|c|c|c|c|}
\hline & \multirow{2}{*}{$\mathrm{N}$} & \multirow{2}{*}{ Min- Max } & \multirow{2}{*}{ Mean \pm SD } & \multicolumn{5}{|c|}{ Parameters of length-weight relationships } \\
\hline & & & & $\mathrm{b}$ & $\mathrm{a}$ & $\pm 95 \% \mathrm{CI}$ & $\mathrm{r}^{2}$ & G T \\
\hline Females & 179 & $\begin{array}{l}15-26.8 \mathrm{~cm} \\
51.7-283.9 \mathrm{~g}\end{array}$ & $\begin{array}{c}20.61 \pm 2.31 \mathrm{~cm} \\
144.54 \mathrm{~g} \pm 51.25 \mathrm{~g}\end{array}$ & 3.13 & 0.0106 & $3.012-3.244$ & 0.968 & $\mathrm{~A}+$ \\
\hline Males & 273 & $\begin{array}{l}14.5-27.2 \mathrm{~cm} \\
40.8-293.2 \mathrm{~g}\end{array}$ & $\begin{array}{c}18.81 \pm 2.08 \mathrm{~cm} \\
107.78 \mathrm{~g} \pm 42.88\end{array}$ & 3.13 & 0.0106 & $2.999-3.261$ & 0.936 & $\mathrm{~A}+$ \\
\hline Unsexed & 14 & $\begin{array}{l}12.7-17 \mathrm{~cm} \\
38.1-70.4 \mathrm{~g}\end{array}$ & $\begin{array}{c}15.24 \mathrm{~cm} \pm 1.57 \mathrm{~cm} \\
54.47 \mathrm{~g} \pm 13.28\end{array}$ & --- & --- & --- & --- & --- \\
\hline Al samples & 466 & $\begin{array}{l}12.7-27.2 \mathrm{~cm} \\
38.1-293.2 \mathrm{~g}\end{array}$ & $\begin{array}{l}19.52 \mathrm{~cm} \pm 2.34 \mathrm{~cm} \\
120.27 \mathrm{~g} \pm 50.31 \mathrm{~g}\end{array}$ & 3.129 & 0.0107 & $3.100-3.272$ & 0.960 & $\mathrm{~A}+$ \\
\hline
\end{tabular}

\section{Otolith morphometry and age determination}

The overall otolith shape was ovate to elongate (Fig. 3). No significant differences in the morphometric measures were detected between the left and right otoliths. Paired test was observed at $P>0.05$ for all sizes and between both sexes (ANCOVA, $P>0.05$ for all measures), so the data were pooled for both sexes and the mean data for each sagittal otolith were studied with more analyses (Table 2). A linear model described correlation between the fish total length/ or weight and otolith morphometry measures, with high coefficients of determination $(\geq 0.87)$ (Table 3$)$.

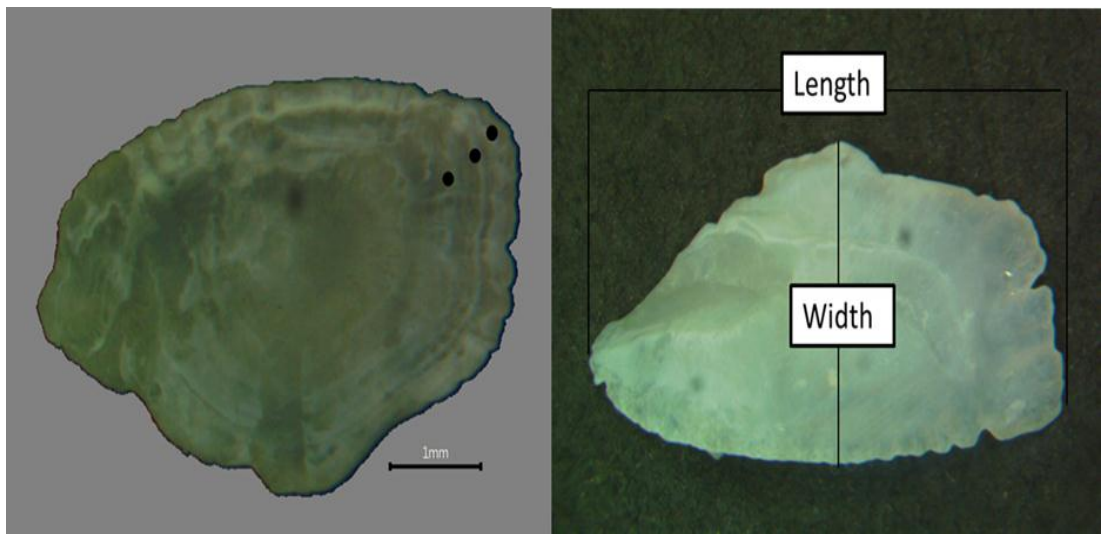

Fig. 3. Otolith of $R$. haffara (Length $22.5 \mathrm{~cm}$, age 3yrs) and measurements with scale bar $=1 \mathrm{~mm}$. 
Table 2. Principal otolith parameters of R. haffara sampled in Hurghada, Red Sea.

\begin{tabular}{ccc} 
Parameters & Min - Max & Mean \pm SD \\
OW $(\mathbf{g})$ & $0.0117-0.0457$ & $0.0204 \pm 0.0060$ \\
\hline OL $(\mathbf{m m})$ & $5.28-8.25$ & $6.50 \pm 0.69$ \\
\hline OH $(\mathbf{m m})$ & $2.38-4.17$ & $3.40 \pm 0.34$ \\
\hline AS $(\mathbf{m m})$ & $0.42-0.63$ & $0.52 \pm 0.03$
\end{tabular}

$\mathrm{SD}=$ standard deviation; $\mathrm{OW}=$ otolith weight; $\mathrm{OL}=$ otolith length; $\mathrm{OH}=$ otolith width; $\mathrm{AS}=$ aspect ratio.

Table 3. Parameters of the linear regression between the total length or weight and the otolith parameters of $R$. haffara sampled from Hurghada, Red Sea, Egypt.

\begin{tabular}{llc} 
Relation & \multicolumn{1}{c}{ Equation } & $\mathbf{R}^{\mathbf{2}}$ \\
\hline TL vs. OW & $\mathrm{TL}=0.402 \mathrm{x}+1.9709$ & 0.7832 \\
TL vs. OL & $\mathrm{TL}=1.1104 \mathrm{x}+0.3843$ & 0.8741 \\
TL vs. OH & $\mathrm{TL}=1.0697 \mathrm{OH}+0.7187$ & 0.8187 \\
TL vs. AS & $\mathrm{TL}=-0.1043 \mathrm{As}+1.255$ & 0.0023 \\
W vs. OW & $\mathrm{W}=1.3037 \mathrm{x}+4.2717$ & 0.7727 \\
W vs. OL & $\mathrm{W}=3.5898 \mathrm{x}-0.8644$ & 0.8572 \\
W vs. OH & $\mathrm{W}=3.4003 \mathrm{x}+0.2474$ & 0.7761 \\
W vs. $\mathbf{A S}$ & $\mathrm{W}=-0.5359 \mathrm{x}+1.8947$ & 0.0056
\end{tabular}

The age observations are essential for almost all aspects of the fishery investigators but particularly for studies on the age, growth, production and population dynamics. A total of 466 otoliths from fish ranging from 12.7-27.2 cm total length were read and used in the determination of the parameters of the growth. Age was determined by counting the opaque rings on the otoliths. Alternative pairs of the translucent and opaque zones were considered a year annulus. The whole otolith readings indicated good agreement between the different estimates (agreement $=88.35 \%, \mathrm{CV}=3.928 \%$ and $\mathrm{APE}=2.777 \%$ ).

The maximum observed age was 5 years for the males and females. The females backcalculated lengths corresponding to various age groups were 15.09, 19.58, 22.64, 24.69 and $26.44 \mathrm{~cm}$ at the end of the $1^{\text {st }}, 2^{\text {nd }}, 3^{\text {rd }}, 4^{\text {th }}$ and $5^{\text {th }}$ years, respectively. On the other hand, the males back-calculated lengths corresponding to various age groups were 15.00, 19.66, 23.04, 25.42 and $26.85 \mathrm{~cm}$ at the end of the $1^{\text {st }}, 2^{\text {nd }}, 3^{\text {rd }}, 4^{\text {th }}$ and $5^{\text {th }}$ years, respectively. The results revealed that there is no significant difference in back-calculated lengths between the two sexes. 
The growth model of the von Bertalanffy (Fig. 4) yielded the following parameters K, $\mathrm{L}_{\infty}, \mathrm{W}_{\infty}$ and $\mathrm{t}_{0}$ for $R$. haffara. For females: $\mathrm{K}=0.35 \mathrm{y}^{-1}, \mathrm{~L}_{\infty}=30.13 \mathrm{~cm}, \mathrm{~W}_{\infty}=451.51 \mathrm{~g}$ and $\mathrm{t}_{0}=-$ $0.24 \mathrm{y}$ and for males: $\mathrm{K}=0.36 \mathrm{y}^{-1}, \mathrm{~L}_{\infty}=30.49 \mathrm{~cm}, \mathrm{~W}_{\infty}=468.41 \mathrm{~g}$ and $\mathrm{t}_{0}=-0.26 \mathrm{y}$, while for sexes combined: $\mathrm{K}=0.36 \mathrm{y}^{-1}, \mathrm{~L}_{\infty}=30.47 \mathrm{~cm}, \mathrm{~W}_{\infty}=470.21 \mathrm{~g}$ and $\mathrm{t}_{0}=-0.25 \mathrm{y}$. The von Bertalanffy growth model equations for $R$. haffara were:

Females $\quad \mathrm{L}_{\mathrm{t}}=30.13\left(1-\mathrm{e}^{-0.35(\mathrm{t}+0.24)}\right) \quad$ for growth in length

Females $\quad \mathrm{W}_{\mathrm{t}}=451.51\left(1-\mathrm{e}^{-0.35(\mathrm{t}+0.24)}\right)^{3.13}$ for growth in weight

Males $\quad \mathrm{L}_{\mathrm{t}}=30.49\left(1-\mathrm{e}^{-0.36(\mathrm{t}+0.26)}\right) \quad$ for growth in length

Males $\quad \mathrm{W}_{\mathrm{t}}=468.41\left(1-\mathrm{e}^{-0.36(t+0.26)}\right)^{3.13}$ for growth in weight

These results translated into similar growth-performance indices for females $\left(\varnothing^{\prime}=2.50\right)$ and males $\left(\varnothing^{\prime}=2.53\right)$. The estimated growth performance for all specimens was $\emptyset^{\prime}=2.53$.

Maximum age $\left(\mathbf{t}_{\max }\right)$ :

The potential longevity of $R$. haffara from the Egyptian Red Sea was observed to be 8.4, 8 and 7.8 years for females, males and all samples, respectively.

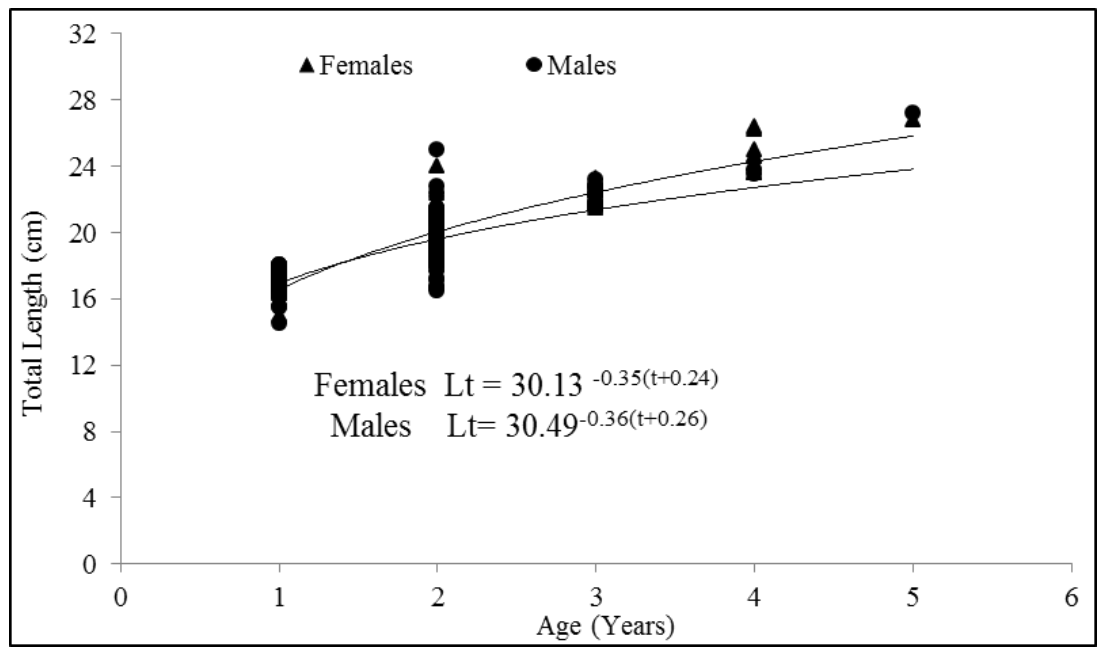

Fig. 4. Von Bertalanffy growth model of $R$. haffara from Hurghada fishing area, Egypt.

\section{DISCUSSION}

Our results illustrated that the relative growth and the relationships between the fish length and otolith size are valuable measures in fisheries management research. For the application of these measures, morphometric variables from data collected in the field should be transformed into appropriate indices. First, the analysis of the length-frequency data can be used for the estimation of the age, growth, survival, mortality rates and analytical yield models such as the yield per recruit (Beverton and Holt, 1966; Gulland,1971; Pauly, 1984).

Second, the length weight relationship, (b) value is sometime used to show the robustness of the fish (Le Cren, 1951). It was stated that the value of exponent (b) gives the isometric mode of growth if it is equal 3, while the mode is considered allometric if it is significantly different from three. The comparable length- weight relationship equations in the 
present work and previous work for the same species are summarized in table (4). The slope values (b) of the length-weight relationships for females and males are the same $(b=3.13$ for males and females) and for all samples the b-value was 3.129. These values and their confidence intervals indicated a positive allometric growth. The present study estimated a bigger length than previous studies at different localities (Al Abdulhadi and Osman, 2007; ElDrawany, 2015; Mehanna, 2001). The obtained b-value for the combined sexes of $R$. haffara (3.129) was higher than that estimated by Mehanna (2001) who mentioned that the growth of $R$. haffara from Suez Bay was negative allometric $(\mathrm{b}=2.94)$, while it was close to the value obtained by El-Drawany (2015) who got $b=3.101$ indicating a positive allometric growth. The variation in the type of growth may be due to environmental changes, food availability, feeding rate, different localities and other ecological factors (Bagenal and Tesch, 1978). The temporal effect is related to the spawning season (Mahé et al., 2017), length composition of the sampled species and the period of sampling (Moutopoulos and Stergiou, 2002; Mehanna and AlMamry, 2012).

The maximum life span in the present study was higher than that estimated by the previous studies. The age estimation based on the scales' readings was four years for length range from 9 to $24.2 \mathrm{~cm}$ TL (Mehanna, 2001) and from 9.0 to $21.0 \mathrm{~cm}$ TL (El-Drawany, 2015). The difference in the age determination between the present and previous works is understandable due to the difference in the observed maximum size. The difference in age can be attributed to a number of factors such as ecological parameters, sex, method of age determination, the range of fish size and different habitats.

Table 4. Length-weight relationship of $R$. haffara compared with the previous studies

\begin{tabular}{|c|c|c|c|c|c|c|}
\hline Author & Location & $\begin{array}{c}\text { Weight range } \\
\text { (g) }\end{array}$ & $\begin{array}{c}\text { Length range } \\
(\mathrm{cm})\end{array}$ & $\mathbf{a}$ & $\mathbf{b}$ & $\mathbf{r}$ \\
\hline Mehanna (2001) & Suez Bay & $10-207$ & $9-24.2$ & 0.01742 & 2.940 & 0.996 \\
\hline $\begin{array}{l}\text { Al Abdulhadi and } \\
\text { Osman (2007) }\end{array}$ & Dammam & & & 0.013 & 3.11 & \\
\hline El-Drawany (2015) & Lake Timsah & $18.5-205.3$ & 9- 21 & 0.01756 & 3.101 & 0.992 \\
\hline Present study & Hurghada & $\begin{array}{c}\text { F: } 51.7-283.9 \\
\text { M: } 40.8-293.2 \\
\text { All: } 38.1-293.2\end{array}$ & $\begin{array}{c}15-26.8 \\
14.5-27.2 \\
12.7-27.2 \\
\end{array}$ & $\begin{array}{l}0.0106 \\
0.0106 \\
0.0107\end{array}$ & $\begin{array}{c}3.13 \\
3.13 \\
3.129 \\
\end{array}$ & $\begin{array}{l}0.968 \\
0.936 \\
0.953\end{array}$ \\
\hline
\end{tabular}

In the present study, four variables describing whole otolith morphometry were significantly correlated with the age of $R$. haffara. Several authors showed that a significant relationship between the otolith weight and fish (McDougall, 2004; Ochwada et al., 2008; Doering-Arjes et al., 2008; Steward et al., 2009; Matić-Skoko et al., 2011; Williams et al., 2015; Mahé et al., 2016).

The mean otolith weight, length, and width increased with age, but the aspect ratio fluctuated with the age of $R$. haffara, implying that these morphometric parameters may provide 
a satisfactory method of ageing. A power model described all relations between otolith morphometries and fish age, and according to Škeljo et al. (2012), this model may result from the specific otolith growth rates of the younger fish. The age of the haffara sea bream can be best predicted from the otolith length with high correlation. Additionally, the observed oval otolith shape is specific for $R$. haffara and therefore might be used as a powerful tool in the identification of species and determination of fish prey identity in feeding studies (Bilge and Gülşahin, 2014).

Growth parameters ( $\mathrm{L} \infty, \mathrm{K}$ and to) were the main input data into different models used for managing and evaluating the status of the exploited fish stocks. These parameters are usefully used in comparison between the growth of fish belonging to varied species or to the same species at different times and different localities (Mehanna, 1996). The present growth parameters with those reported from the previous studies were shown in table 5. The present study gives higher $\left(\mathrm{L}_{\infty}\right)$ than the previous studies (Mehanna, 2001; Al Abdulhadi ans Osman, 2007; El-Drawany, 2015) for the same species in the Suez Bay and Lake Timsah (Suez Canal, Egypt). The differences in the growth parameters may be due to the differences in the recorded maximum length and/or due to the difference in environmental conditions.

Growth performance indices were used to comprise the growth rate of fish with other species (Pauly and Munro, 1984). In this study, the growth performance index ( $\left.\emptyset^{\prime}\right)$ of $R$. haffara was 2.53 for the sexes combined. The growth performance index estimated in the current work indicates that Hurghada fishing ground is better for $R$. haffara growth than the other localities.

Table 5. The von Bertalnffy growth peremters compared with the privous studies.

\begin{tabular}{|c|c|c|c|c|c|c|c|}
\hline Author & Location & $\mathbf{L}_{\max }(\mathbf{c m})$ & $\mathbf{L}_{\infty}(\mathbf{c m})$ & $\mathbf{W}_{\infty}(\mathrm{g})$ & $\mathbf{K}\left(\mathbf{y r}^{-1}\right)$ & $t_{0}(y r s)$ & $\boldsymbol{\theta}$ \\
\hline Mehanna (2001) & Suez Bay & 24.2 & 26.79 & 275 & 0.47 & -0.36 & \\
\hline $\begin{array}{l}\text { Al Abdulhadi and } \\
\text { Osman (2007) }\end{array}$ & Dammam & & 27.74 & 399.95 & 0.17 & -1.85 & 2.12 \\
\hline El-Drawany (2015) & $\begin{array}{c}\text { Lake } \\
\text { Timsah }\end{array}$ & 21 & 27.4 & 505 & 0.1125 & -1.34 & \\
\hline \multirow{3}{*}{ Present study } & \multirow{3}{*}{ Hurghada } & F: 26.8 & 30.13 & 451.51 & 0.35 & -0.24 & 2.50 \\
\hline & & M: 27.2 & 30.49 & 468.41 & 0.36 & -0.26 & 2.53 \\
\hline & & All: 27.2 & 30.47 & 470.21 & 0.36 & -0.26 & 2.53 \\
\hline
\end{tabular}

\section{CONCLUSION}

Rhabdosargus haffara collected from Hurghada fishing area fast growth species $(\mathrm{k}=$ 0.36 for all samples). Age validation based on reading the whole otoliths by two readers showed best precision (agreement $=88.35 \%, \mathrm{CV}=3.928 \%$ and $\mathrm{APE}=2.777 \%$ ). This study indicated the importance of the age and growth parameters on the accurate evaluation of the stock dynamics of $R$. haffara at Hurghada and provides the estimates of these parameters for any future studies dealing with the stock assessment and management of this species in Hurghada fishing ground, Egypt. 


\section{REFERENCES}

Al Abdulhadi, H. A. and Osman, A. M. (2007). Reproductive biology of Rhabdosargus haffara (Teleostei, Sparidae) in the Arabian Gulf. Egyp. J. Aquat. Res., 2009., 35(2): 175-179.

Al Mamry, J.; McCarthy, I.; Richardson, C. and Ben Meriem, S. (2009). Biology of the kingsoldier bream (Argyrops spinifer, Forsskål 1775; Sparidae), from the Arabian Sea, Oman. J Appl. Ichthyol., 25: 559-564.

Bagenal, T. and Tesch A. (1978). Conditions and growth patterns in fresh water habitats. Blackwell Scientific Publications, Oxford.

Bauchot, M. L. and Smith, M. M. (1984). Sparidae. In W. Fischer and G. Bianchi (eds.) FAO species identification sheets for fishery purposes. Western Indian Ocean (Fishing Area 51). volume 4. [var. pag.] FAO, Rome.

Beamish, R. J. and Fournier, D. A. (1981). A method of comparing the precision of a set of age determinations. Can. J. Fish. Aquat. Sci. 38, 982-983.

Beverton, R. J. and Holt, S. J. (1966). Manual of methods for fish stock assessment: Part 2-tables of yield functions. Food and Agriculture Organization of the United Nations.

Bilge, G. and Gülşahin, A. (2014). Relationship between sagittal otolith size and fish size in Argentina sphyraena and Glossanodon leioglossus (Osteichthyes: Argentinidae) in the southern Aegean Sea, Turkey. Zool. Middle. East., 60: 24-28.

Doering-Arjes, P.; Cardinale, M. and Mosegaard, H. (2008). Estimating population age structure using otolith morphometrics: a test with known-age Atlantic cod (Gadus morhua) individuals. Can. J Fish. Aqut. Sci., 65: 2342-2350.

El-Drawany, M. (2015). Age, growth and mortality of Rhabdosargus haffara in Lake Timsah, (Suez Canal, Egypt).

Ferri, J.; Brčić, J.; Škeljo, F.; Sršen, L. and Uvodić, A. (2017). A preliminary study on the age and growth of the argentine, Argentina sphyraena (Actinopterygii: Osmeriformes: Argentinidae) from the eastern Adriatic Sea. ACTA Ichthy. de Pisc., 47: 365-369.

Fischer, W. and Bianchi, G. (1984). FAO species identification sheets for fishery purposes: Western Indian Ocean (Fishing Area 51). FAO, Rome.

Ford, E. (1933). An account of the herring investigations conducted at Plymouth during the years from 1924 to 1933. J Mar. Biol. Assoc. UK., 19: 305-384.

Gulland, J. (1971). The Fish Resources Of The Ocean. West Byfleet, Surrey. Fishing News (Books), Ltd., for FAO: 255pp.

Kuiter, R. H. and Tonozuka, T. (2001). Pictorial guide to Indonesian reef fishes. Zoonetics.

Le Cren, E. (1951). The length-weight relationship and seasonal cycle in gonad weight and condition in the perch (Perca fluviatilis). J Anim. Ecol.,201-219.

Mahé, K.; Rabhi, K.; Bellamy, E.; Elleboode, R.; Aumond, Y.; Huet, J.; Cresson, P. and Roos, D. (2016). Growth of the oblique-banded grouper (Epinephelus radiatus) on the coasts of Reunion Island (SW Indian Ocean). Cybium, 40: 61-65.

Mahé, K.; Aumond, Y.; Rabhi, K.; Elleboode, R.; Bellamy, E.; Huet, J.; Gault, M. and Roos, D. (2017). Relationship between somatic growth and otolith growth: a case study of the ornate jobfish Pristipomoides argyrogrammicus from the coast of Réunion (SW Indian Ocean). African J Mar. Sci., 39 (2); 145-151. 
Matić-Skoko, S.; Ferri, J.; Škeljo, F.; Bartulović, V.; Glavić, K. and Glamuzina, B. (2011). Age, growth and validation of otolith morphometrics as predictors of age in the forkbeard, Phycis phycis (Gadidae). Fish. Res., 112: 52-58.

Mc Dougall, A. (2004). Assessing the use of sectioned otoliths and other methods to determine the age of the centropomid fish, barramundi (Lates calcarifer)(Bloch), using known-age fish. Fish. Res., 67: 129-141.

Mehanna, S. F. (1997). The study of biology and population dynamics of Lethrinus mahsena in the Gulf of Suez), PhD Thesis, Faculty of Science, Zagazig University.

Mehanna, S. F. (2001). Growth, mortality and yield per recruit of Rhabdosargus haffara (Sparidae) from the Suez Bay. Egyp. Aquat. Biol. Fish., 5: 31-46.

Mehanna, S. F. (2007). A preliminary assessment and management of gilthead bream Sparus aurata in Port Said fishery, Southeastern Mediterranean, Egypt. Tur. J. Fish. Aquat. Sci., 7 (2): 123-130.

Mehanna, S. F.; Zaki, S.; Al-kiuymi, F. R.; Al-Kharusi, L. and Al-Jardani, S. (2012). Precision of Age Estimation in Goldlined Seabream Rhabdosargus sarba (Sparidae) from the Arabian Sea, Oman. J Biol. Agricul. Heal., 2 (9): 60-71.

Mehanna, S. F.; Al-Kiyumi, F. R. and Al-Kharusi, L. (2012). Population dynamics and management of goldlined seabream Rhabdosargus sarba (Sparidae) from the Oman coast of Arabian Sea. Fish. Aquacul. Journal., 2012: 1-9

Mehanna, S. F. and Al-Mammry, J. (2012). Length-weight relationship of 19 pelagic and demersal fish species from the sea of Oman. 4th International conference on Fisheries and Aquaculture researches, Cairo, 3-6 October, 2012

Mehanna, S. F.; El-Azim, H.A. and Belal, A. A. (2016). Impact of metal pollution, food availability, and excessive fishing on Rhabdosargus haffara stock (family: Sparidae) in Timsah lake. Environ. Sci. Pollut. Res., 23: 15888-15898.

Moutopoulos, D. and Stergiou, K. (2002). Length-weight and length-length relationships of fish species from the Aegean Sea (Greece). J Appl. Ichthyol., 18: 200-203.

Ochwada, F. A.; Scandol, J. P. and Gray, C. A. (2008). Predicting the age of fish using general and generalized linear models of biometric data: a case study of two estuarine finfish from New South Wales, Australia. Fish. Res., 90: 187-197.

Pauly, D. (1983). Some simple methods for the assessment of tropical fish stocks. FAO.

Pauly, D. (1984). Length-converted catch curves: a powerful tool for fisheries research in the tropics. Fishbyte (Philippines).

Pauly, D. and Munro, J. (1984). Once more on the comparison of growth in fish and invertebrates. Fishbyte (Philippines).

Siddiqui, S. A. A. and Masroor, R. (2014). The sparid fishes of Pakistan, with new distribution records. Zoot., 3857: 071-100.

Škeljo, F.; Ferri, J.; Brčić, J.; Petrić, M. and Jardas, I. (2012). Age, growth and utility of otolith morphometrics as a predictor of age in the wrasse Coris julis (Labridae) from the eastern Adriatic Sea. Sci. Mar., 76: 587-595.

Steward, C. A.; DeMaria, K. D. and Shenker, J. M. (2009). Using otolith morphometrics to quickly and inexpensively predict age in the gray angelfish (Pomacanthus arcuatus). Fish. Res., 99: 123-129.

von Bertalanffy, L. (1938). A quantitative theory of organic growth (inquiries on growth laws. II). Human biol., 10: 181-213.

Walford, L. A. (1946). A new graphic method of describing the growth of animals. Biol. Bull., 90: 141147. 
